\title{
Hydroxyl Group and Vasorelaxant Effects of Perillyl Alcohol, Carveol, Limonene on Aorta Smooth Muscle of Rats
}

\author{
Ana Carolina Cardoso-Teixeira ${ }^{1}$, Francisco Walber Ferreira-da-Silva ${ }^{2}$, \\ Dieniffer Peixoto-Neves ${ }^{3}{ }^{[0}$, Klausen Oliveira-Abreu ${ }^{1}$, Átila Pereira-Gonçalves ${ }^{1}$, \\ Andrelina Noronha Coelho-de-Souza ${ }^{1}$ and José Henrique Leal-Cardoso ${ }^{1, *}$ \\ 1 Superior Institute of Biomedical Sciences, State University of Ceará, Fortaleza-CE 60741-903, Brazil; \\ carol.cardoso@uece.br (A.C.C.-T.); klausen.abreu@aluno.uece.br (K.O.-A.); \\ atila.pereira@aluno.uece.br (Á.P.-G.); andrelinanoronha@gmail.com (A.N.C.-d.-S.) \\ 2 Civil Engineering Department, State University of Vale do Acaraú, Sobral-CE 62042-280, Brazil; \\ walber_ferreira@uvanet.br \\ 3 Department of Physiology, University of Tennessee Health Science Center, Memphis, TN 38163, USA; \\ dneves@uthsc.edu \\ * Correspondence: jose.cardoso@uece.br; Tel.: +55-85-3101-9814
}

Received: 22 May 2018; Accepted: 3 June 2018; Published: 13 June 2018

\begin{abstract}
The present study used isometric tension recording to investigate the vasorelaxant effect of limonene (LM), carveol (CV), and perillyl alcohol (POH) on contractility parameters of the rat aorta, focusing in particular on the structure-activity relationship. $\mathrm{LM}, \mathrm{CV}$, and $\mathrm{POH}$ showed a reversible inhibitory effect on the contraction induced by electromechanical and pharmacomechanical coupling. In the case of $\mathrm{LM}$, but not $\mathrm{CV}$ and $\mathrm{POH}$, this effect was influenced by preservation of the endothelium. $\mathrm{POH}$ and $\mathrm{CV}$ but not LM exhibited greater pharmacological potency on BayK-8644-induced contraction and on electromechanical coupling than on pharmacomechanical coupling. In endothelium-denuded preparations, the order of pharmacological potency on electrochemical coupling was $\mathrm{LM}<\mathrm{CV}<\mathrm{POH}$. These compounds inhibited also, with grossly similar pharmacological potency, the contraction induced by phorbol ester dibutyrate. The present results suggest that LM, $\mathrm{CV}$ and $\mathrm{POH}$ induced relaxant effect on vascular smooth muscle by means of different mechanisms likely to include inhibition of PKC and IP3 pathway. For CV and POH, hydroxylated compounds, it was in electromechanical coupling that the greater pharmacological potency was observed, thus suggesting a relative specificity for a mechanism likely to be important in electromechanical coupling, for example, blockade of voltage-dependent calcium channel.
\end{abstract}

Keywords: structure-activity relationship; limonene; carveol; perillyl alcohol; vascular smooth muscle; vasorelaxant effect

\section{Introduction}

Monoterpenes and monoterpenoids, the major chemical components of essential oils, are made of two isoprene units [1,2]. They have shown several pharmacological activities such as antioxidant, anti-inflammatory, antiedematogenic, gastroprotective, and anti-hypertensive [3-7]. In addition, monoterpenes have been reported to exert significant effects on the cardiovascular system [8]. Carvacrol, thymol, eugenol, methyleugenol, 1,8-cineole, and terpinen-4-ol are small monoterpenoids, which exhibited vasorelaxant effects on isolated rat aorta [9-14]. Moreover, 1,8-cineole and citronellol have been reported to elicit hypotension in normotensive rats $[15,16]$. 
Several studies have investigated the correlation between the chemical structure of monoterpenes and their biological/pharmacological activity. For example, the presence of oxygen on the monoterpenoid molecule contributes to the relaxant activity of rotundifolone on both ileum and mesenteric artery $[17,18]$. Additionally, the position of ketone and epoxide groups on terpenes and terpenoids influences their vasorelaxant activity on rat mesenteric arteries [17]. Previous studies also demonstrated the importance of the hydroxyl group $(-\mathrm{OH})$ of terpenoids in blocking the compound action potential of sciatic nerves and on ionic channel activity [19-22]. Accordingly, the presence and position of functional groups such as the hydroxyl group, may influence the pharmacological potency and efficacy of these molecules.

Three molecules are particularly suitable to evaluate the activity of the hydroxyl group on contractile properties of vascular smooth muscle (VSM): limonene (LM), carveol (CV), and perillyl alcohol (POH) (Figure 1). These terpenoid molecules share a similar structure; however, LM does not have the $-\mathrm{OH}$ group, $\mathrm{POH}$ is a primary alcohol, and $\mathrm{CV}$ is a secondary alcohol [23]. LM, a monocyclic monoterpene constituent of several citrus essential oils, has antinociceptive, gastroprotective, antitumor, and anti-inflammatory properties [24-27]. CV and $\mathrm{POH}$, hydroxylated metabolites of LM, have repellent and anticarcinogenic properties [2,28,29]. Regarding cardiovascular activities, LM has been shown to relax the superior mesenteric artery in rats and $\mathrm{POH}$ has been reported to have a hypotensive effect and relaxant activity on the coronary artery in pigs $[17,30,31]$. The vasorelaxant effect of CV on smooth muscle preparations has not been described yet. As LM and POH are known to exert pharmacological activities on VSM and CV is likely to exert it due to molecular similarity to LM and $\mathrm{POH}$, the present study compared the acute vascular effects of $\mathrm{LM}, \mathrm{CV}$, and $\mathrm{POH}$ on the rat aorta. We also studied the possible implications stemming from the presence/absence of the hydroxyl group on this vasorelaxant effect.

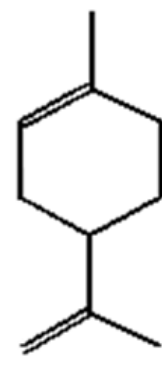

Limonene

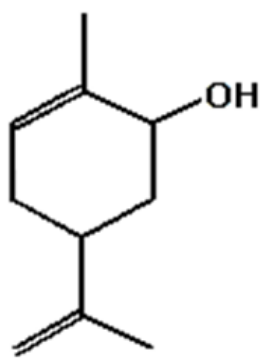

Carveol

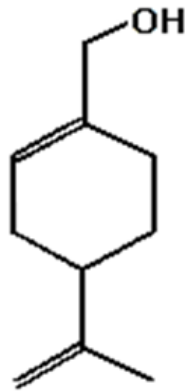

Perillyl Alcohol

Figure 1. Chemical structure of the monoterpene limonene and monoterpenoids carveol and perillyl alcohol [8].

\section{Results}

\subsection{Effect of Limonene, Carveol, and Perillyl Alcohol on the Resting Tonus of Rat Aortic Rings}

First, the effect of $\mathrm{LM}, \mathrm{CV}$, and $\mathrm{POH}$ was investigated on the aorta resting tone. Cumulative concentrations $(1-5000 \mu \mathrm{M})$ of $\mathrm{CV}$ or $\mathrm{POH}$ did not significantly alter the resting tone when compared to the control ( $n=5, p>0.05$, ANOVA) in quiescent endothelium-intact aortic rings (Figure 2). In contrast, LM caused a significant increase of resting tone $(n=6 ; p<0.05$, one-way ANOVA, followed by Holm-Sidak test) at a concentration of 1000 (0.99 $\pm 0.01 \mathrm{~g}$ in control vs. $1.35 \pm 0.15 \mathrm{~g}$, following LM exposure), 2000 (0.99 $\pm 0.01 \mathrm{~g}$, vs. $1.43 \pm 0.18 \mathrm{~g}), 3000$ (0.99 $\pm 0.02 \mathrm{~g}$, vs. $1.43 \pm 0.16 \mathrm{~g})$, and $5000 \mu \mathrm{M}$ $(1.01 \pm 0.03 \mathrm{~g}$, vs. $1.42 \pm 0.17 \mathrm{~g})$. The vehicle had no significant effect on the resting tone of aortic rings (Figure 2). 


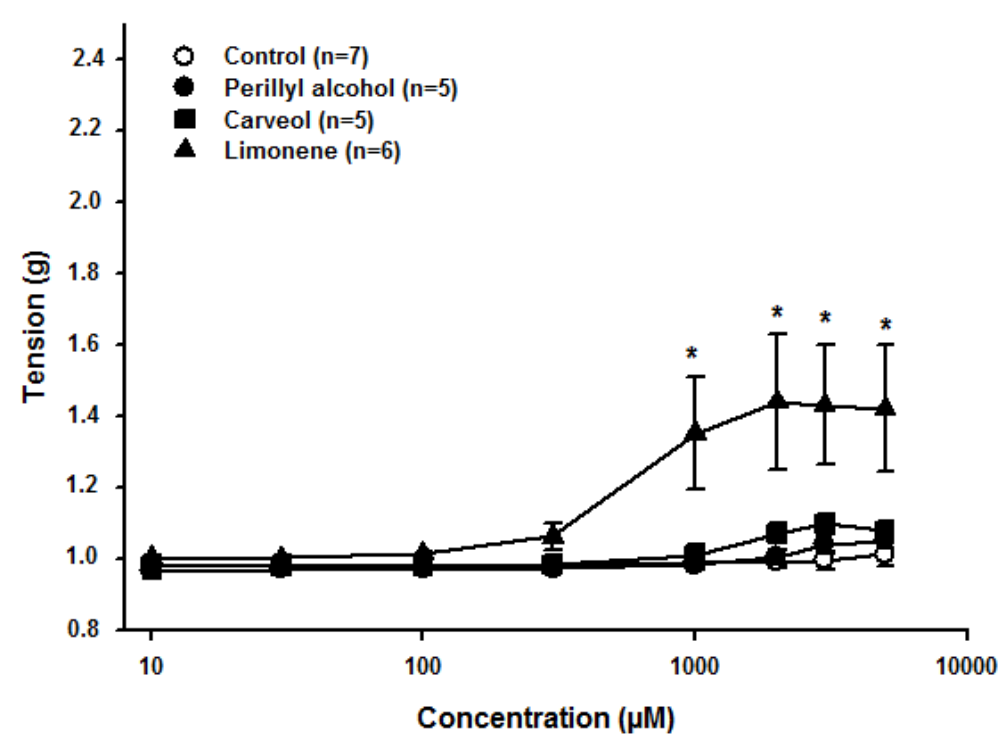

Figure 2. Effects of limonene, carveol, and perillyl alcohol on the resting tonus of rat aortic rings. * indicates statistical difference compared to the control $(p<0.05$, one-way ANOVA and Holm-Sidak test). Each control consisted of the same concentration of vehicle as in the experimental case, but without the experimental substance.

2.2. Relaxant Effect of Limonene, Carveol, and Perillyl Alcohol on the Sustained Contraction Induced by $\mathrm{KCl}$ in Rat Aortic Rings

To investigate the effect of monoterpene and monoterpenoids on electromechanical coupling (EMC), increasing concentrations $(10-5000 \mu \mathrm{M})$ of $\mathrm{LM}, \mathrm{CV}$, and $\mathrm{POH}$ were added to the organ chamber during the plateau of $\mathrm{KCl}$-induced contraction. Addition of $\mathrm{LM}(n=6), \mathrm{CV}(n=7)$, and $\mathrm{POH}(n=6)$ induced a significant concentration-dependent relaxation $(p<0.05$, two-way ANOVA followed by Holm-Sidak test) on endothelium-intact arteries, with $\mathrm{EC}_{50}$ values (concentration at which $50 \%$ of the maximal response was observed) of 941.6, 662.1, and 277.7 $\mu \mathrm{M}$ respectively (Figure 3A and Table 1). Endothelium denudation significantly attenuated relaxation induced by LM but not that stimulated by $\mathrm{POH}$ and $\mathrm{CV}$.

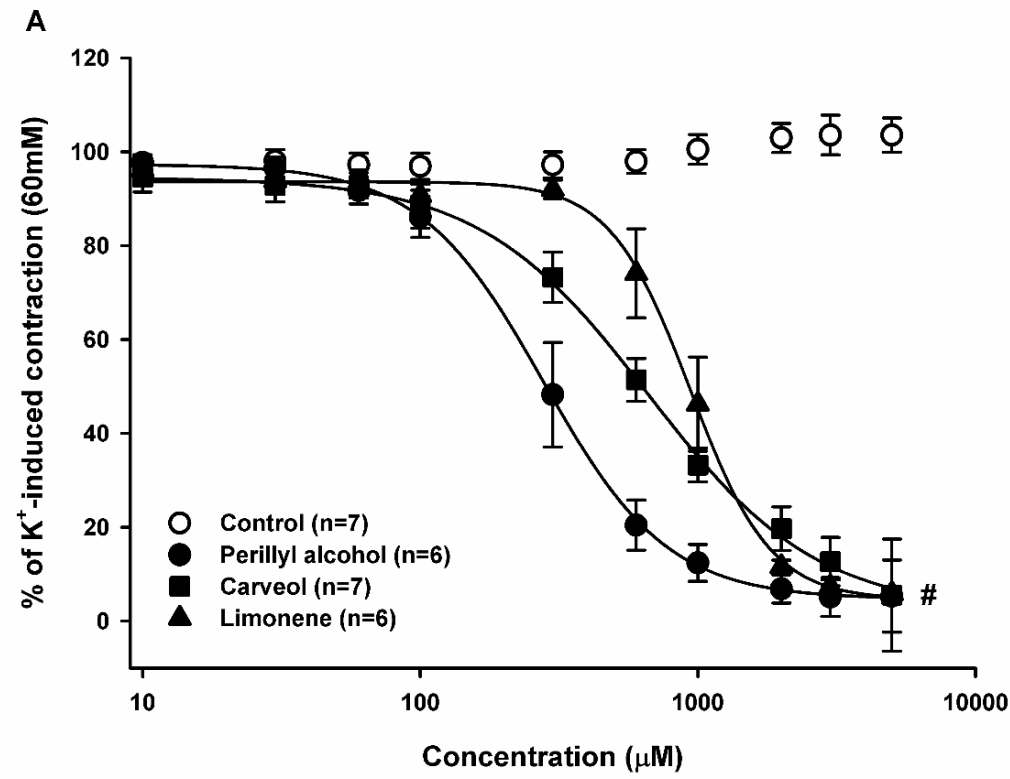

Figure 3. Cont. 


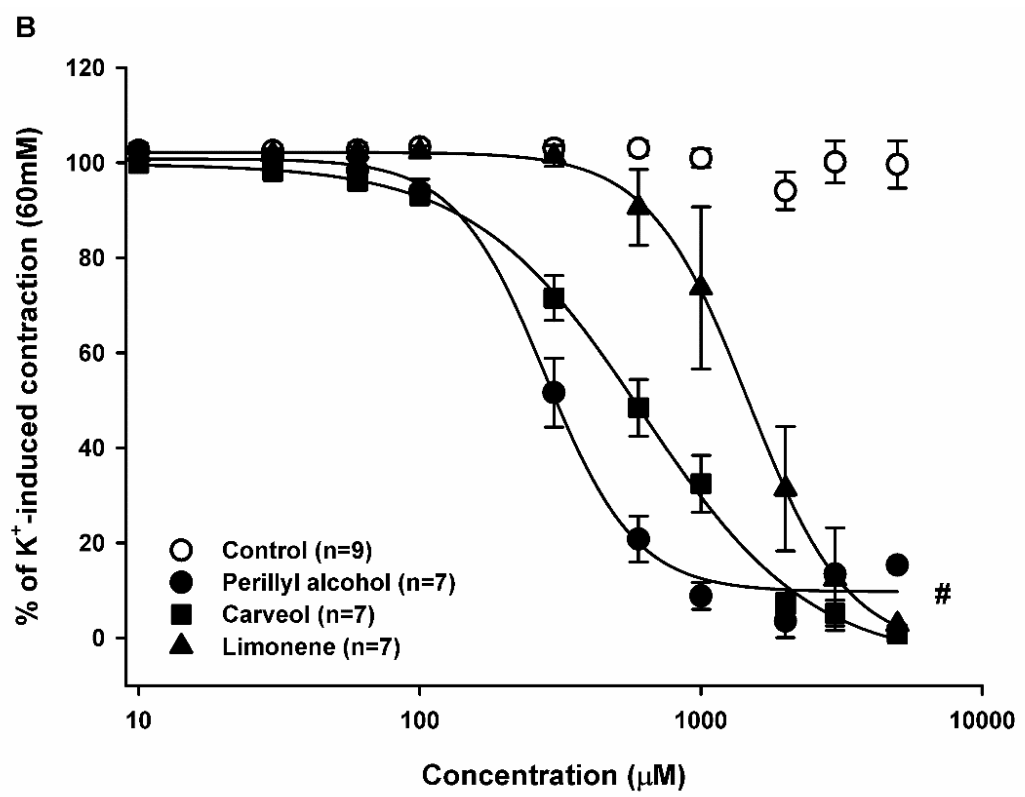

Figure 3. Relaxant effect of limonene, carveol, and perillyl alcohol on electromechanical coupling. Sustained contractions induced by $\mathrm{K}^{+}(60 \mathrm{mM})$ in endothelium-intact $(A)$ and endothelium-denuded (B) rat aortic rings. Results are shown as means \pm SEM. \# indicates statistical difference of limonene, carveol, and perillyl alcohol compared to the control ( $p<0.05$, two-way ANOVA and Holm-Sidak test). Each control consisted of the same concentration of vehicle as in the experimental case, but without the experimental substance.

Table 1. $\mathrm{EC}_{50}$ values summarizing the relaxant effects of perillyl alcohol, carveol, and limonene on rat aortic rings. Values are expressed as means \pm SEM.

\begin{tabular}{ccccc}
\hline Contractile Agent & & Perillyl Alcohol $(\mu \mathrm{M})$ & Carveol $(\mu \mathrm{M})^{\text {Limonene }(\mu \mathrm{M})}$ \\
\hline $\mathrm{K}^{+}$ & E+ & $277.7 \pm 5.46(6)$ & $662.1 \pm 32.85(7)^{\mathrm{a}}$ & $941.6 \pm 28.02(6)^{\mathrm{b}}$ \\
$\mathrm{K}^{+}$ & E- & $279.7 \pm 22.01(7)$ & $619.8 \pm 37.15(7)^{\mathrm{a}}$ & $1474.5 \pm 27.08(7)^{\mathrm{b}, \mathrm{c}}$ \\
PHE & E+ & $443.3 \pm 66.83(6)^{\mathrm{d}}$ & $1333.3 \pm 225.20(10)^{\mathrm{a}, \mathrm{e}}$ & $2159.1 \pm 203.62(7)^{\mathrm{b}, \mathrm{f}}$ \\
PHE & E- & $433.3 \pm 44.31(7)^{\mathrm{d}}$ & $1237.34 \pm 117.90(9)^{\mathrm{a}, \mathrm{e}}$ & $1216.7 \pm 57.50(7)^{\mathrm{c}, \mathrm{f}}$ \\
BayK & E- & $221.4 \pm 4.09(5)$ & $598.2 \pm 42.05(5)^{\mathrm{a}}$ & $439.0 \pm 31.76(5)^{\mathrm{b}, \mathrm{g}}$ \\
\hline
\end{tabular}

E+, endothelium-intact aorta; E-, endothelium-denuded aorta; PHE, phenylephrine; ${ }^{a}, p<0.05$, in compared to the corresponding $\mathrm{POH}$ value; ${ }^{\mathrm{b}}, p<0.05$, compared to the corresponding $\mathrm{CV}$ value; ${ }^{\mathrm{c}}, p<0.05$, endothelium-intact vs. endothelium-denuded; ${ }^{\mathrm{d}}, p<0.05$, compared to $277.7,279.7$, and $221.4 \mu \mathrm{M} ;{ }^{\mathrm{e}}, p<0.05$ compared to $662.1,619.8$, and $598.2 \mu \mathrm{M} ;{ }^{\mathrm{f}}, p<0.05$, compared to $941.6,1474.5$, and $439.0 \mu \mathrm{M} ; \mathrm{g}, p<0.05$, BayK vs. limonene $\mathrm{K}^{+} \mathrm{E}+$ and $\mathrm{K}^{+} \mathrm{E}-$; Values are expressed as means $\pm \operatorname{SEM}(n), n=$ number of experiments.

In endothelium-denuded arteries, $\mathrm{LM}(n=7), \mathrm{CV}(n=7)$, and $\mathrm{POH}(n=7)$ produced significant vascular relaxation ( $p<0.05$, two-way ANOVA followed by Holm-Sidak test), with $\mathrm{EC}_{50}$ values of $1474.5,619.8$, and $279.7 \mu \mathrm{M}$, respectively (Figure 3B and Table 1). The relaxations caused by LM, CV, and $\mathrm{POH}$ were reversible after washing (data not shown).

\subsection{Relaxant Effect of Limonene, Carveol, and Perillyl Alcohol on the Sustained Contraction Induced by Phenylephrine (PHE) in Rat Aortic Rings}

The effect of monoterpenes and monoterpenoids on pharmacomechanical coupling (PMC) was investigated in aortic preparations pre-contracted with PHE $(0.1 \mu \mathrm{M})$. In endothelium-containing tissue, LM ( $n=7)$ induced two distinct responses: a contraction in the $300-1000 \mu \mathrm{M}$ range (with a significant peak at $600 \mu \mathrm{M}$ ), and a concentration-dependent relaxation at higher amounts. The latter was significant at concentrations above $2000 \mu \mathrm{M}$. As seen in Figure $4 \mathrm{~A}, \mathrm{CV}(n=10)$ and $\mathrm{POH}(n=6)$ 
did not exert a contraction but solely induced a concentration-dependent relaxation. Calculated $\mathrm{EC}_{50}$ values were 2159.1, 1333.3, and $443.3 \mu \mathrm{M}$ for $\mathrm{LM}, \mathrm{CV}$, and $\mathrm{POH}$, respectively (Figure $4 \mathrm{~A}$, Table 1).
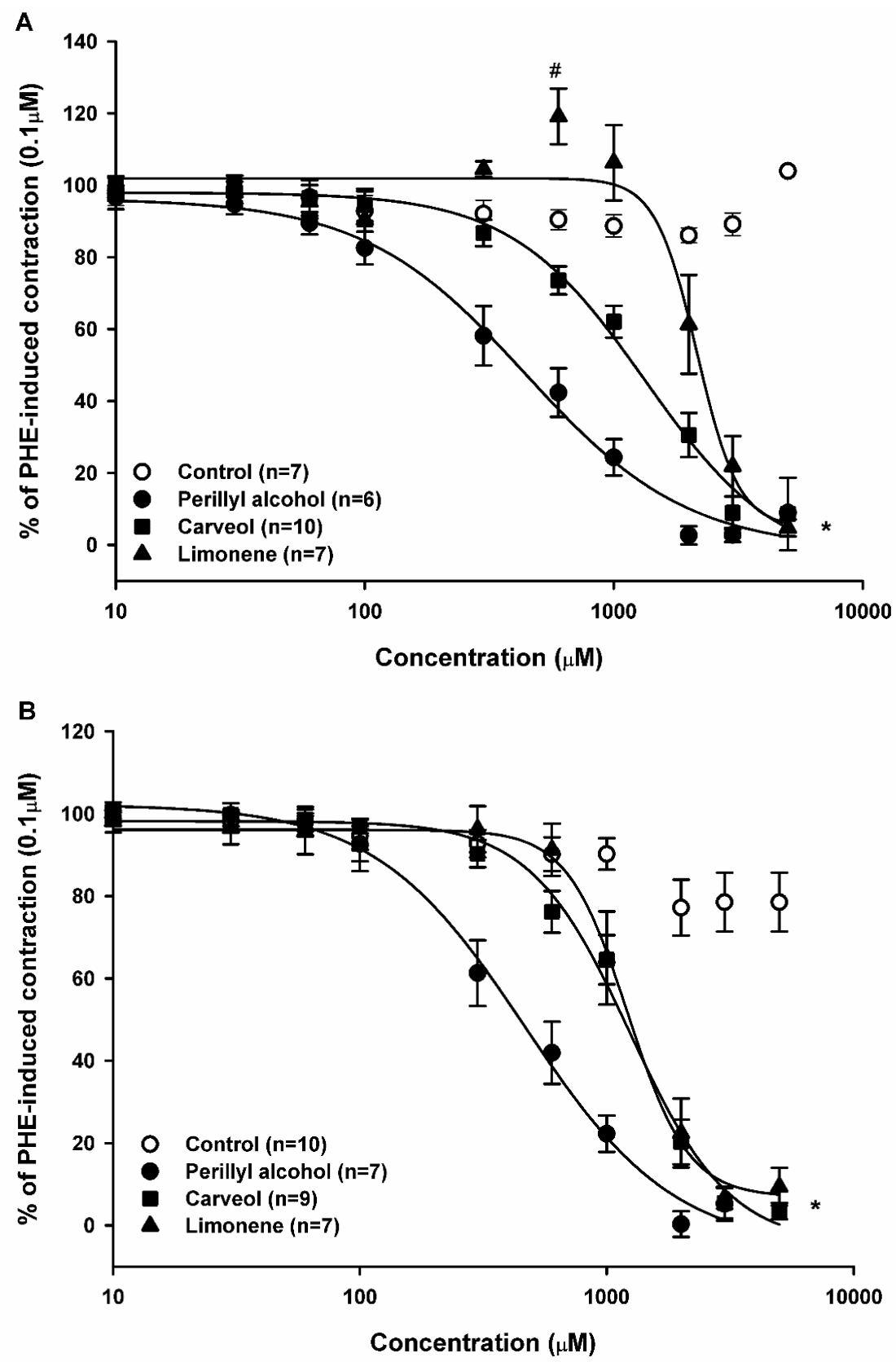

Figure 4. Relaxant effect of limonene, carveol, and perillyl alcohol on pharmacomechanical coupling. Sustained contractions induced by PHE $(0.1 \mu \mathrm{M})$ in endothelium-intact $(\mathbf{A})$ and endothelium-denuded (B) rat aortic rings. Results are shown as means \pm SEM. * indicates statistical difference of limonene, carveol, and perillyl alcohol compared to the control ( $p<0.05$, two way ANOVA and Holm-Sidak test). \# indicates statistical difference between limonene $(600 \mu \mathrm{M})$ compared to the control $(p<0.05$, one-way ANOVA and Holm-Sidak test). Each control consisted of the same concentration of vehicle as in the experimental case, but without the experimental substance.

Endothelium denudation significantly altered LM-induced contraction and relaxation, but not $\mathrm{CV}$ - and POH-induced effects. In endothelium-denuded arteries, the relaxing effect of LM $(n=7)$, $\mathrm{CV}(n=9)$, and POH $(n=7)$ was statistically significant $(p<0.05$, two-way ANOVA followed by 
Holm-Sidak test) with $\mathrm{EC}_{50}$ values of $1216.7,1237.3$, and $433.3 \mu \mathrm{M}$ for $\mathrm{LM}, \mathrm{CV}$, and $\mathrm{POH}$, respectively (Figure 4B, Table 1).

\subsection{Relaxant Effect of Perillyl Alcohol, Carveol, and Limonene on Sustained Contractions Induced by BayK-8644}

The effect of monoterpenes on contractions induced by BayK-8644, an L-type $\mathrm{Ca}^{2+}$ channel activator, was investigated. $\mathrm{POH}(30-3000 \mu \mathrm{M}), \mathrm{CV}$, and LM (both 100-3000 $\mu \mathrm{M}$ ) relaxed, in a concentration-dependent manner, the contractions of endothelium-containing aortic preparations induced by BayK-8644 $(2 \mu \mathrm{M})$, and then sensitized with $\left[\mathrm{K}^{+}\right](10 \mathrm{mM})$ and maintained in $\mathrm{Ca}^{2+}$-containing medium. The relaxant effect of $\mathrm{POH}(n=5)$ and $\mathrm{CV}(n=5)$ was statistically significant compared to the control (Figure 5; $p<0.05$, two-way ANOVA followed by Holm-Sidak test) with $\mathrm{EC}_{50}$ values of 221.4 and $598.2 \mu \mathrm{M}$, respectively. These values were similar to those obtained for the vasorelaxant effects of $\mathrm{POH}$ and $\mathrm{CV}$ on contractions induced by $60 \mathrm{mM}\left[\mathrm{K}^{+}\right]$. For $\mathrm{LM}(n=5)$, the relaxant effect was statistically significant compared to the control (Figure 5; $p<0.05$, two-way ANOVA followed by Holm-Sidak test) with an $\mathrm{EC}_{50}$ value of $439.0 \mu \mathrm{M}$. However, LM did not cause full relaxation of the aortic preparation in the concentration range used.

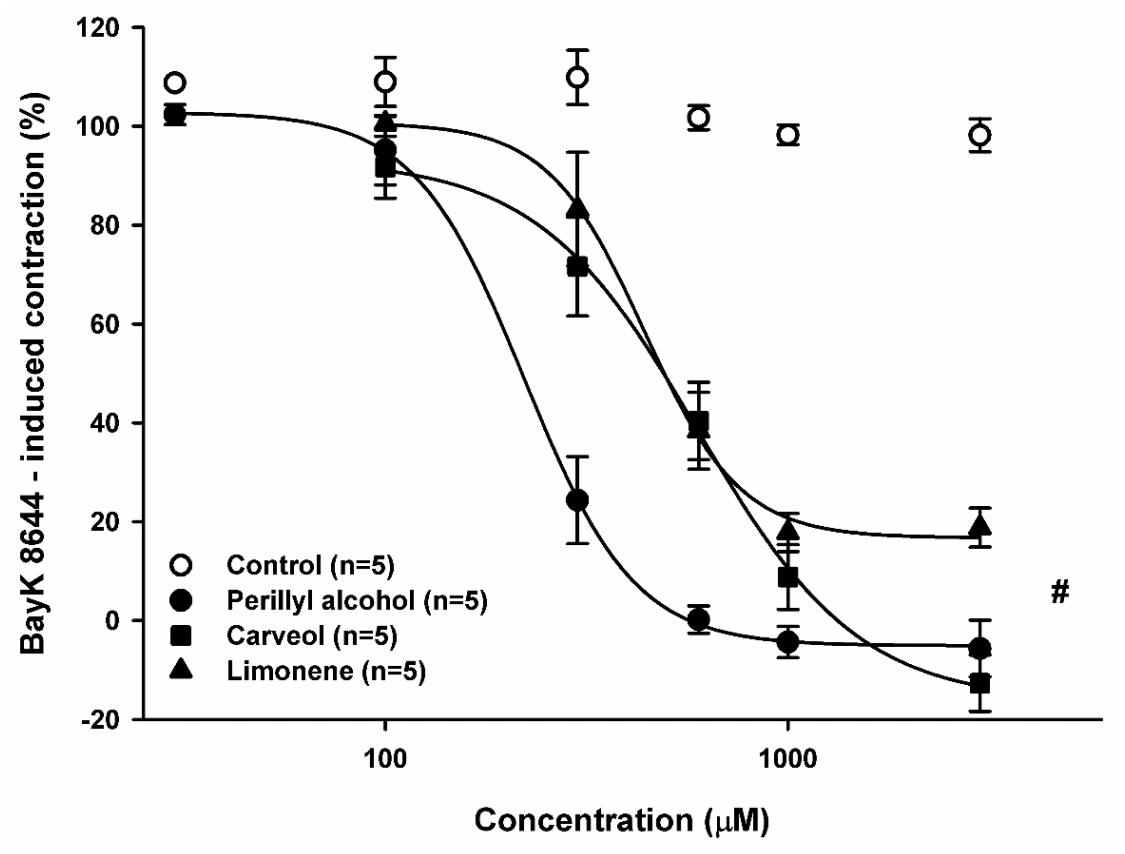

Figure 5. Relaxant Effect of perillyl alcohol, carveol, and limonene on sustained contractions induced by BayK-8644 $(2 \mu \mathrm{M})$ in endothelium-denuded rat aortic rings. Results are shown as means \pm SEM. \# indicates statistical difference between limonene, carveol, and perillyl alcohol vs. control $(p<0.05$, two-way ANOVA and Holm-Sidak test). Each control consisted of the same concentration of vehicle as in the experimental case, but without the experimental substance.

\subsection{Effect of Limonene, Carveol, and Perillyl Alcohol on the Sustained Contraction Induced by Phorbol} 12,13-Dibutyrate (PDB) in Rat Aortic Rings

To investigate the effect of $\mathrm{LM}$ and its analogs in $\mathrm{Ca}^{2+}$ sensitization, we used PDB $(1 \mu \mathrm{M})$, a protein kinase $\mathrm{C}$ (PKC) activator [32]. In endothelium-denuded aortic rings incubated in $\mathrm{Ca}^{2+}$-free medium and in the presence of thapsigargin $(1 \mu \mathrm{M})$, a calcium pump inhibitor [33], PDB induced slow and sustained contractions with a mean tension of $1.39 \pm 0.08 \mathrm{~g}$. LM and POH significantly reduced PDB-induced contraction by 42.63 and $55.75 \%$, respectively, at $2000 \mu \mathrm{M}$ and by 63.49 and $108.77 \%$, respectively, at $3000 \mu \mathrm{M}$ (Figure 6). CV significantly inhibited PDB-induced contraction only at $3000 \mu \mathrm{M}$, resulting in a total $(101.69 \%)$ blockade. 


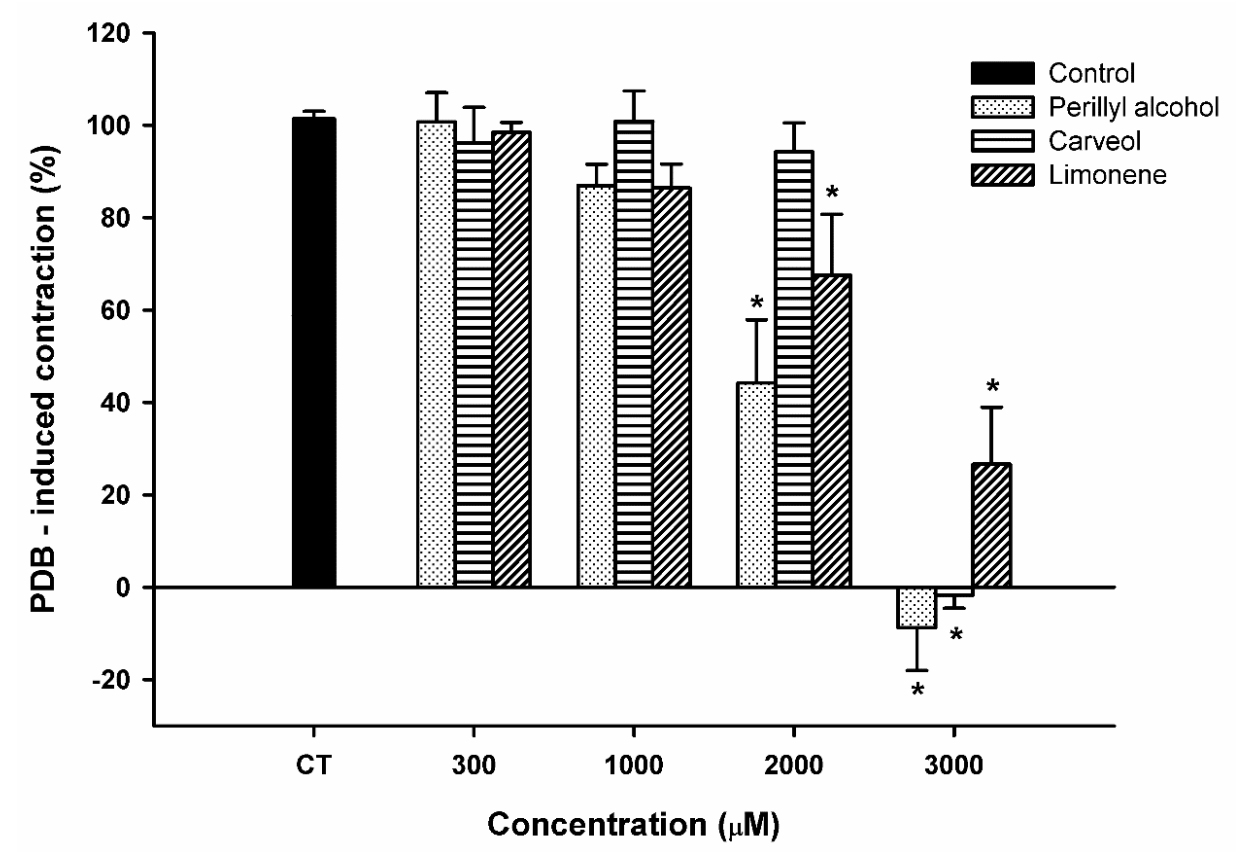

Figure 6. Relaxant effect of perillyl alcohol, carveol, and limonene on sustained contractions induced by PDB $(1 \mu \mathrm{M})$ in endothelium-denuded rat aortic rings. Results are shown as means \pm SEM. * indicates a significant effect ( $p<0.05$, ANOVA on Rank's followed by Dunn's test).

\section{Discussion}

The present study compared for the first time the effect of $\mathrm{POH}, \mathrm{CV}$, and LM on VSM in the rat aorta. Our main finding indicates that $\mathrm{POH}, \mathrm{CV}$, and $\mathrm{LM}$ had a relaxant effect on several types of contraction. Moreover, in spite of a similar molecular structure, substances with a $-\mathrm{OH}$ group had relative specificity for blocking the EMC.

We here investigated the effect of $\mathrm{POH}, \mathrm{CV}$, and $\mathrm{LM}$ on two types of excitation-contraction coupling: EMC and PMC. In terms of EMC, all substances had a relaxant effect in $\mathrm{K}^{+}$-induced contraction. In EMC, intracellular $\mathrm{Ca}^{2+}$ concentration $\left(\left[\mathrm{Ca}^{2+}\right]_{\mathrm{i}}\right)$ increases after direct activation of voltage-operated $\mathrm{Ca}^{2+}$ channels (VOCCs) following membrane depolarization, thus leading to contraction [34]. $\mathrm{POH}$ and $\mathrm{CV}$ relaxed the tonus of aortic ring preparations, which was artificially increased by adding $60 \mathrm{mM}\left[\mathrm{K}^{+}\right]$to the bathing solution, promoting cytoplasmic membrane depolarization to values close to $-15 \mathrm{mV}$ and outward $\mathrm{K}^{+}$rectification [35]. This depolarization shows that the effect elicited by $\mathrm{POH}$ and $\mathrm{CV}$ is independent of primary trans-membrane electric potential alteration. At this transmembrane potential, VOCCs are activated, increasing $\mathrm{Ca}^{2+}$ inflow to the cytoplasm and triggering EMC. Given that VOCC activation is essential for vasoconstriction in EMC, we hypothesized that inhibition of $\mathrm{K}^{+}$-induced contraction by $\mathrm{POH}$ and $\mathrm{CV}$ was caused by direct VOCC blockade. To corroborate this point, $\mathrm{POH}$ and $\mathrm{CV}$ showed smaller $\mathrm{EC}_{50}$ values in $\mathrm{EMC}$ than in PMC (Table 1). We therefore tested whether both monoterpenoids blocked contraction induced by BayK-8644, an agonist of L-type VOCCs [36]. Consistent with our hypothesis, POH and CV inhibited BayK-8644 contraction. Furthermore, inhibition of BayK-8644-induced contraction occurred with similar pharmacological potency and efficacy as during blockade of $\mathrm{K}^{+}$-induced contraction (Table 1), indicating that $\mathrm{POH}$ and $\mathrm{CV}$ inhibit $\mathrm{K}^{+}$-induced contraction likely to blocking L-type VOCC.

Comparison of $\mathrm{EC}_{50}$ values and pharmacological efficacy on blocking EMC in preparations with and without endothelium, showed no difference between $\mathrm{CV}$ and $\mathrm{POH}$. This indicates that their effects on EMC during VSM contraction are not modulated by endothelial factors.

Similarly to our results, previous studies suggested that some terpenes and terpenoids, such as terpinen-4-ol, thymol, carvacrol, eugenol, and trans-caryophyllene, relaxed smooth muscles via VOCC 
blockade $[9,10,37,38]$. This provides further support to our hypothesis that $\mathrm{CV}$ and $\mathrm{POH}$ relaxation of VSM preparations involves blocking VOCCs in the plasma membrane.

Concerning PMC, all substances promoted relaxation of VSM in this type of contraction. An increase in $\left[\mathrm{Ca}^{2+}\right]_{i}$ is necessary for VSM contraction; it can be triggered by agonist-induced activation of membrane receptors which, in turn, activate receptor-operated $\mathrm{Ca}^{2+}$ channels (ROCC) [39]. In this study, we used PHE and PDB as agonists to activate PMC. PHE is an $\alpha 1$-adrenoceptor agonist, which induces $\mathrm{Ca}^{2+}$ influx through ROCC, promotes $\mathrm{Ca}^{2+}$ release from the sarcoplasmic reticulum, and results in $\mathrm{Ca}^{2+}$ sensitization of contractile proteins [40]. $\alpha 1$-adrenoceptor activation initially elicits a phasic contraction component, with $\mathrm{Ca}^{2+}$ release from the sarcoplasmic reticulum promoted by interaction between inositol trisphosphate $\left(\mathrm{IP}_{3}\right)$ and $\mathrm{IP}_{3}$ receptors, followed by a sustained tonic phase [40]. In the tonic phase, contraction is sustained by $\mathrm{Ca}^{2+}$ influx through ROCC and $\mathrm{Ca}^{2+}$-independent pathways. These pathways involve contractile machinery sensitization by biochemical intracellular substance like PKC [41]. The full blockade of PHE-induced contraction shows that $\mathrm{POH}$ and $\mathrm{CV}$ could block all components of this contraction, suggesting that, although with smaller pharmacological potency, there are other mechanisms of action involved besides VOCC blockade. Additionally, comparison of $\mathrm{POH}$ and $\mathrm{CV}^{\mathrm{EC}} \mathrm{C}_{50}$ values for blocking PHE-stimulated PMC, shows no modulation by the endothelium, as already observed during EMC.

Our data on the effect of $\mathrm{CV}$ and $\mathrm{POH}$ on PHE-induced contraction differ from previously reported findings, whereby other terpenoids' pharmacological effect was modulated by the endothelium [10,14,42]. This is important because in some diseases such as arterial hypertension, the endothelium is damaged and its influence is lost [43]. Moreover, it shows the richness and variety of pharmacological effects of these natural terpenoids.

LM was the only substance without a -OH group in its molecule. Its activity on $\mathrm{K}^{+}$- and PHE-induced contractions showed a strikingly different pharmacological activity profile, compared to $\mathrm{POH}$ and $\mathrm{CV}$. In general, its pharmacological potency was smaller and was partially dependent on endothelium preservation. In endothelium-denuded preparations, the pharmacological potency of LM in blocking $\mathrm{K}^{+}$- and PHE-induced contractions varied significantly and was much greater during PMC. The opposite occurred during EMC, whereby preparations with preserved endothelium showed increased pharmacological potency. Accordingly, the absence of $-\mathrm{OH}$ not only decreased the potency, but also the relative specificity of $\mathrm{POH}$ and $\mathrm{CV}$ in causing this effect. The impact of the endothelium on $\mathrm{LM}$ treatment was not surprising, as the endothelium releases several factors that modify the intensity of muscle contraction [44,45]. It should be noted that the alcohols $\mathrm{POH}$ and $\mathrm{CV}$ are more potent than non-alcoholic $\mathrm{LM}$ and a comparison of $\mathrm{EC}_{50}$ values on endothelium-denuded preparations showed the order of pharmacological efficacy to be: $\mathrm{LM}<\mathrm{CV}<\mathrm{POH}$.

BayK-8644 induces contraction by L-type VOCC activation [36]. Assuming that inhibition of BayK-8644-induced contraction was due to blockade of VOCCs, then the $\mathrm{EC}_{50}$ values for blocking of BayK-8644- and $60 \mathrm{mM} \mathrm{K}^{+}$-induced contractions were expected to be similar. This was indeed the case for $\mathrm{POH}$ and $\mathrm{CV}$, but not for LM. Nevertheless, the result for LM does not invalidate the assumption of VOCC blockade in the case of $\mathrm{POH}$ and CV. The antagonistic effect of a given agent might rely on different mechanisms. For example, nifedipine and verapamil block BayK-8644 contraction via competitive and non-competitive mechanisms, respectively [46], and this could be the case also for LM. Although we do not know the mechanism of LM blockade for BayK-8644-induced contraction, it is reasonable to suggest that it differs from that of $\mathrm{POH}$ and CV. This would explain why LM could only partially $(<80 \%)$ block BayK-8644-induced contractions.

$\mathrm{POH}, \mathrm{CV}$, and LM could inhibit the contraction induced by PDB, a phorbol ester. PDB acts primarily as a PKC activator and causes $\mathrm{Ca}^{2+}$ sensitization of the contractile machinery, eliciting contraction without substantial changes in myoplasmic $\mathrm{Ca}^{2+}$ concentration [32,47]. In the present study, PDB used a mechanism of action that did not involve $\mathrm{Ca}^{2+}$ inflow to the cell, as this set of experiments was performed in $\mathrm{Ca}^{2+}$-free solution. $\mathrm{POH}, \mathrm{CV}$, and $\mathrm{LM}$ acted with grossely similar pharmacological potency on PDB-induced contraction (Figure 6). They all showed greater potency in 
blocking EMC than on PDB contraction. This fact reinforces the suggestion that the three substances employ several mechanisms of action and that presence of $-\mathrm{OH}$ on the molecule increases the potency on $\mathrm{EMC}$, as shown also by $\mathrm{EC}_{50}$ values.

This effect shows that LM may induces mechanisms that triggers contraction, for example, release calcium from sarcoplasmatic reticulum like other monoterpenes [9]. Furthermore, in endothelium-intact preparations, but not in endothelium-denuded, LM showed a potentiating effect in PMC at $600 \mu \mathrm{M}$. Taken together, these results suggest that endothelium participate on contraction effects induced by LM, perhaps by means of release of contraction-inducing factors, such as, prostaglandins $[48,49]$, endothelin [50,51] or other unknown factor.

The three monoterpenes in this study were able to relax contractions elicited by both EMC and PMC in a concentration-dependent manner. However, their potencies differed with respect to presence and position of the $-\mathrm{OH}$ group. Comparison of $\mathrm{EC}_{50}$ values in endothelium-denuded preparations revealed this order of pharmacological potency: $\mathrm{LM}<\mathrm{CV}<\mathrm{POH}$. The hydroxylated molecules, $\mathrm{CV}$ and $\mathrm{POH}$, exhibited greater relaxant effects than non-hydroxylated LM. Among the hydroxylated compounds, $\mathrm{POH}$, a primary alcohol (i.e., $-\mathrm{OH}$ is attached to a primary carbon atom) and very hydrophilic, is more potent than $\mathrm{CV}$, a secondary alcohol. Thus, the observed order of pharmacological potency reflects the degree of hydrophilicity imparted by the presence and position of the - $\mathrm{OH}$ group. Several studies support our hypothesis that $-\mathrm{OH}$ is important for the pharmacological and biological activity of these compounds [20,52].

Interestingly, some studies demonstrated the importance of the-OH group in monoterpenoids for their action on ion channels. During TRPV3 activation, for example, the six most potent monoterpenes carried a hydroxyl group, whereas none of the compounds without an oxygen moiety (p-cymene and (+)-limonene) affected the channel to a significant extent [22]. These studies strengthen our hypothesis that $\mathrm{CV}$ and $\mathrm{POH}$ may act on muscle cells by affecting ion channels such as VOCCs.

\section{Materials and Methods}

\subsection{Animals}

Male Wistar rats, weighing 200-300 g, were kept under conditions of constant temperature $\left(23 \pm 2{ }^{\circ} \mathrm{C}\right)$ with a $12 \mathrm{~h}$ light $/ 12 \mathrm{~h}$ dark cycle and free access to food and water. All animals were handled in compliance with the Guide for the Care and Use of Laboratory Animals, 8th edition, published by the US National Institutes of Health in 2011 (https: / /www.nap.edu/read/12910/chapter/1) and all efforts were made to minimize animal suffering. All procedures were approved by the Animal Care and Use Committee of the State University of Ceará (process approval number 12237313-0).

\subsection{Solutions and Drugs}

Krebs Henseleit's solution (KHS) was used as bathing solution with the following composition: $118 \mathrm{mM} \mathrm{NaCl}, 4.7 \mathrm{mM} \mathrm{KCl}, 25 \mathrm{mM} \mathrm{NaHCO} 3,2.5 \mathrm{mM} \mathrm{CaCl}_{2} \cdot 2 \mathrm{H}_{2} \mathrm{O}, 1.2 \mathrm{mM} \mathrm{KH} \mathrm{PO}_{4}, 1.2 \mathrm{mM}$ $\mathrm{MgSO}_{4} \cdot 7 \mathrm{H}_{2} \mathrm{O}, 11 \mathrm{mM}$ glucose, and $0.01 \mathrm{mM}$ EDTA. The KHS was constantly aerated $\left(5 \% \mathrm{O}_{2}\right.$, $95 \% \mathrm{CO}_{2}$ ) and the $\mathrm{pH}$ was adjusted to 7.40 with $\mathrm{NaOH} / \mathrm{HCl}$. In experiments requiring $\mathrm{Ca}^{2+}$-free solutions, equimolar substitution of $\mathrm{CaCl}_{2}$ with EGTA $(2 \mathrm{mM})$ was carried out. The agonists PHE and acetylcholine (Ach) were first dissolved in distilled water to make stock solutions. $\mathrm{LM}, \mathrm{CV}$, and $\mathrm{POH}$ were first diluted in Tween 80 (final concentration $\leq 0.05 \%$ ). BayK-8644, PDB, and thapsigargin were first diluted in dimethyl sulfoxide (final concentration $\leq 0.05 \%$ ). All stock solutions were sonicated immediately before addition to the experimental chamber to attain the final desired concentration. All reagents were of analytical grade and were purchased from Sigma Chemical Co. (St. Louis, MO, USA), Reagen (Rio de Janeiro, RJ, Brazil), or Vetec (Rio de Janeiro, RJ, Brazil). 


\subsection{Isometric Tension Recording}

Tissue preparation and isometric tension recordings were made as previously reported [10]. Briefly, rats were sacrificed by $\mathrm{CO}_{2}$ inhalation followed by exsanguination. The thoracic aorta was dissected and connective tissue was removed in KHS. Afterwards, the aorta was cut transversally into cylindrical segments of approximately $4 \mathrm{~mm}$ in length and these were mounted on an isolated organ chamber containing $\mathrm{KHS}$ gassed with $\left(95 \% \mathrm{O}_{2} / 5 \% \mathrm{CO}_{2}\right)$, at $37{ }^{\circ} \mathrm{C}$. Mechanical activity was recorded by an isometric force transducer (FTO3; Grass Instruments Co., Quincy, MA, USA) connected to an acquisition system (PM-1000; CWE Inc., Akron, OH, USA). Aortic rings were stretched with a passive tension of $1 \mathrm{~g}$ and allowed to equilibrate for $60 \mathrm{~min}$. Vessel contractility was then tested by an initial exposure to a high- $\left[\mathrm{K}^{+}\right](60 \mathrm{mM})$ solution. Experiments were performed in the presence or absence of endothelium. When required, the endothelium was denuded by gentle rubbing of the aortic lumen with a stainless steel wire. Successful endothelium removal was confirmed by the absence of relaxation of arteries pre-contracted with PHE $(0.1 \mu \mathrm{M})$ and then exposed to Ach $(1.0 \mu \mathrm{M})$ to induce more than $70 \%$ relaxation.

After assessing tissue viability and the endothelium, the following experiments were performed using the compounds in paired form. For a given experiment, a recording channel was assigned to each substance and one channel solely to the external control. LM, CV, or POH were cumulatively added to the organ chamber to allow for increasing concentrations to be achieved $(1-5000 \mu \mathrm{M})$ and their effect on the resting tone of endothelium-containing aortic rings was evaluated. In a subset of experiments, concentration-dependent responses to $\mathrm{LM}, \mathrm{CV}$, or $\mathrm{POH}$ were measured in endothelium-containing and endothelium-denuded rings pre-contracted with either $60 \mathrm{mM} \mathrm{KCl}$ or $0.1 \mu \mathrm{M}$ PHE. In another series of experiments, the effects of LM, CV, and $\mathrm{POH}$ were compared against the contractions induced by PDB $(1 \mu \mathrm{M})$, a PKC activator [32], in endothelium-denuded rings incubated in $\mathrm{Ca}^{2+}$-free KHS (added $2 \mathrm{mM}$ EGTA) and previous (30 min) addition of thapsigargin (1 $\mu \mathrm{M})$, a calcium pump inhibitor [33]. Relaxant effects of increasing concentrations of LM, CV, and $\mathrm{POH}$ on the sustained contractile response to BayK-8644 $(2 \mu \mathrm{M})$ were studied in endothelium-denuded aortic rings that had been sensitized with extracellular $\left[\mathrm{K}^{+}\right]$of regular KHS increased to $10 \mathrm{mM}$. Control experiments were made in the sole presence of the vehicle (Tween 80 ) at the same concentrations used to dilute the monoterpenes.

\subsection{Statistical Analysis}

Data are expressed as mean \pm standard error of the mean (SEM), where $(n)$ indicates the number of experiments. Concentration-response curve and $\mathrm{EC}_{50}$ values for $\mathrm{LM}, \mathrm{CV}$, and POH were made and adjusted with the Hill equation as follows:

$$
\% \text { of agonist contraction }=\min +\frac{\max -\min }{1+\left(\frac{[\text { agonist }]}{\mathrm{EC}_{50 \%}}\right)^{k}}
$$

where min and max are the minimum and maximum contraction force values, [agonist] is the agonist concentration, and $k$ is the Hill slope. The significance for statistical tests was $p<0.05$ and to compare data from different groups, one- or two-way ANOVA was used, followed by Holm-Sidak's test for parametric data and ANOVA on Rank's followed by Dunn's test for non-parametric data.

\section{Conclusions}

In conclusion, the results show that limonene, carveol and perillyl alcohol have an important relaxant effect on the contractility of vascular smooth muscle cells. $\mathrm{POH}$ and $\mathrm{CV}$ had higher pharmacological potency on the electromechanical coupling, suggesting that a blockade of $\mathrm{Ca}^{2+}$ channels are likely to contribute to the monoterpene-induced vasorelaxation, although we cannot exclude other mechanisms of action, such as, for example, inhibition of $\mathrm{PKC}$ and $\mathrm{IP}_{3}$ pathway. Although 
not crucial for monoterpene bioactivity, the hydroxyl group is relevant for the pharmacological potency of these compounds.

Author Contributions: Conceptualization: A.N.C.-d.-S., PhD and J.H.L.-C., PhD. Methodology: A.N.C.-d.-S., PhD; D.P.-N., PhD; and A.C.C.-T., PhD student; Formal Analysis: K.O.-A., PhD Student and A.C.C.-T., PhD student; Investigation: Á.P.-G., MSc student and A.C.C.-T., PhD student; Writing-Original Draft Preparation: A.C.C.-T., PhD student; Writing-Review \& Editing: F.W.F.-d.-S., PhD; Supervision and Funding Acquisition: J.H.L.-C., PhD.

Funding: This research was funded by Fundação Cearense de Apoio ao Desenvolvimento Científico e Tecnológico-FUNCAP, Coordenação de Aperfeiçoamento de Nível Superior-CAPES and Conselho Nacional de Pesquisa-CNPq.

Acknowledgments: The authors would like to thank Pedro Militão de Albuquerque Neto for technical support and agencies CNPq, CAPES, and FUNCAP for the financial support.

Conflicts of Interest: The authors declare no conflict of interest and the founding sponsors had no role in the design of the study; in the collection, analyses, or interpretation of data; in the writing of the manuscript, and in the decision to publish the results.

\section{References}

1. Chappell, J. The biochemistry and molecular biology of isoprenoid metabolism. Plant Physiol. 1995, 107, 1-6. [CrossRef] [PubMed]

2. Wagner, K.H.; Elmadfa, I. Biological relevance of terpenoids: Overview focusing on mono-, di- and tetraterpenes. Ann. Nutr. Metab. 2003, 47, 95-106. [CrossRef] [PubMed]

3. Yanishlieva, N.V.; Marinova, E.M.; Gordon, M.H.; Raneva, V.G. Antioxidant activity and mechanism of action of thymol and carvacrol in two lipid systems. Food Chem. 1999, 64, 59-66. [CrossRef]

4. Da Rocha, M.L.; Oliveira, L.E.G.; Patrício Santos, C.C.M.; de Sousa, D.P.; de Almeida, R.N.; Araújo, D.A.M. Antinociceptive and anti-inflammatory effects of the monoterpene $\alpha, \beta$-epoxy-carvone in mice. J. Nat. Med. 2013, 67, 743-749. [CrossRef] [PubMed]

5. Ponte, E.; Sousa, P.; Rocha, M.; Soares, P.; Coelho-de-Souza, A.; Leal-Cardoso, J. Comparative study of the anti-edematogenic effects of anethole and estragole. Pharmacol. Rep. 2012, 64, 984-990. [CrossRef]

6. Coelho-de-Souza, A.N.; Lahlou, S.; Barreto, J.E.F.; Yum, M.E.M.; Oliveira, A.C.; Oliveira, H.D.; Celedônio, N.R.; Feitosa, R.G.; Duarte, G.P.; Santos, C.F.; et al. Essential oil of Croton zehntneri and its major constituent anethole display gastroprotective effect by increasing the surface mucous layer. Fundam. Clin. Pharmacol. 2013, 27, 288-298. [CrossRef] [PubMed]

7. Leal-Cardoso, J.H.; Fonteles, M.C. Pharmacological effects of essential oils of plants of the northeast of Brazil. An. Acad. Bras. Cienc. 1999, 71, 207-213. [PubMed]

8. Santos, M.R.V.; Moreira, F.V.; Fraga, B.P.; Souza, D.P.; Bonjardim, L.R.; Quintans-Junior, L.J. Cardiovascular effects of monoterpenes: A review. Rev. Bras. Farmacogn. 2011, 21, 764-771. [CrossRef]

9. Peixoto-Neves, D.; Silva-Alves, K.S.; Gomes, M.D.M.; Lima, F.C.; Lahlou, S.; Magalhães, P.J.; Ceccatto, V.M.; Coelho-de-Souza, A.N.; Leal-Cardoso, J.H. Vasorelaxant effects of the monoterpenic phenol isomers, carvacrol and thymol, on rat isolated aorta. Fundam. Clin. Pharmacol. 2010, 24, 341-350. [CrossRef] [PubMed]

10. Maia-Joca, R.P.M.; Joca, H.C.; Ribeiro, F.J.P.; Do Nascimento, R.V.; Silva-Alves, K.S.; Cruz, J.S.; Coelho-de-Souza, A.N.; Leal-Cardoso, J.H. Investigation of terpinen-4-ol effects on vascular smooth muscle relaxation. Life Sci. 2014, 115, 52-58. [CrossRef] [PubMed]

11. Interaminense, L.F.L.; Leal-Cardoso, J.H.; Caldas Magalhães, P.J.; Pinto, D.G.; Lahlou, S. Enhanced hypotensive effects of the essential oil of Ocimum gratissimum leaves and its main constituent, eugenol, in DOCA-salt hypertensive conscious rats. Planta Med. 2005, 71, 376-378. [CrossRef] [PubMed]

12. Interaminense, L.F.L.; Jucá, D.M.; Magalhães, P.J.C.; Leal-Cardoso, J.H.; Duarte, G.P.; Lahlou, S. Pharmacological evidence of calcium-channel blockade by essential oil of Ocimum gratissimum and its main constituent, eugenol, in isolated aortic rings from DOCA-salt hypertensive rats. Fundam. Clin. Pharmacol. 2007, 21, 497-506. [CrossRef] [PubMed]

13. Lahlou, S.; Interaminense, L.F.L.; Magalhães, P.J.C. Cardiovascular Effects of Eugenol, a Phenolic Compound Present in Many Plant Essential Oils, in Normotensive Rats. J. Cardiovasc. Pharmacol. 2004, 43, 250-257. [CrossRef] [PubMed] 
14. Pinto, N.V.; Assreuy, A.M.; Coelho-de-Souza, A.N.; Ceccatto, V.M.; Magalhães, P.J.C.; Lahlou, S.; Leal-Cardoso, J.H. Endothelium-dependent vasorelaxant effects of the essential oil from aerial parts of Alpinia zerumbet and its main constituent 1, 8-cineole in rats. Phytomedicine 2009, 16, 1151-1155. [CrossRef] [PubMed]

15. Bastos, J.F.A.; Moreira, I.J.A.; Ribeiro, T.P.; Medeiros, I.A.; Antoniolli, A.R.; De Sousa, D.P.; Santos, M.R. Hypotensive and vasorelaxant effects of citronellol, a monoterpene alcohol, in rats. Basic Clin. Pharmacol. Toxicol. 2010, 106, 331-337. [CrossRef] [PubMed]

16. Lahlou, S.; Figueiredo, A.F.; Magalhães, P.J.C.; Leal-Cardoso, J.H. Cardiovascular effects of 1,8-cineole, a terpenoid oxide present in many plant essential oils, in normotensive rats. Can. J. Physiol. Pharmacol. 2002, 80, 1125-1131. [CrossRef] [PubMed]

17. Cardoso-Lima, T.; Mota, M.M.; Barbosa-Filho, J.M.; Viana Dos Santos, M.R.; De Sousa, D.P. Structural relationships and vasorelaxant activity of monoterpenes. Daru 2012, 20, 23. [CrossRef] [PubMed]

18. De Sousa, D.P.; Júnior, G.A.S.; Andrade, L.N.; Calasans, F.R.; Nunes, X.P.; Barbosa-Filho, J.M.; Batista, J.S. Structure and spasmolytic activity relationships of monoterpene analogues found in many aromatic plants. Z. Naturforsch. C 2008, 63, 808-812. [CrossRef] [PubMed]

19. Kawasaki, H.; Mizuta, K.; Fujita, T.; Kumamoto, E. Inhibition by menthol and its related chemicals of compound action potentials in frog sciatic nerves. Life Sci. 2013, 92, 359-367. [CrossRef] [PubMed]

20. Gonçalves, J.; Alves, A.; de Araújo, A.; Cruz, J.; Araújo, D. Distinct effects of carvone analogues on the isolated nerve of rats. Eur. J. Pharmacol. 2010, 645, 108-112. [CrossRef] [PubMed]

21. Mohammadi, B.; Haeseler, G.; Leuwer, M.; Dengler, R.; Krampfl, K.; Bufler, J. Structural requirements of phenol derivatives for direct activation of chloride currents via GABA A receptors. Eur. J. Pharmacol. 2001, 421, 85-91. [CrossRef]

22. Vogt-Eisele, A.K.; Weber, K.; Sherkheli, M.A.; Vielhaber, G.; Panten, J.; Gisselmann, G.; Hatt, H. Monoterpenoid agonists of TRPV3. Br. J. Pharmacol. 2007, 151, 530-540. [CrossRef] [PubMed]

23. Costa, V.V.; da Silva Rocha, K.A.; Oliveira, L.C.A.; Kozhevnikova, E.F.; Kozhevnikov, I.V.; Gusevskaya, E.V. Heteropoly acid catalysts for the synthesis of fragrance compounds from biorenewables: The alkoxylation of monoterpenes. RSC Adv. 2016, 6, 43217-43222. [CrossRef]

24. Murali, R.; Saravanan, R. Antidiabetic effect of d-limonene, a monoterpene in streptozotocin-induced diabetic rats. Biomed. Prev. Nutr. 2012, 2, 269-275. [CrossRef]

25. Rozza, A.; Moraes, T.; Kushima, H.; Tanimoto, A.; Marques, M.; Bauab, T.; Hiruma-Lima, C.A.; Pellizzon, C.H. Gastroprotective mechanisms of Citrus lemon (Rutaceae) essential oil and its majority compounds limonene and $\alpha$-pinene: Involvement of heat-shock protein-70, vasoactive intestinal peptide, glutathione, sulfhydryl compounds, nitric oxide and prostaglandin E. Chem. Biol. Interact. 2011, 189, 82-89. [CrossRef] [PubMed]

26. Hirota, R.; Roger, N.; Nakamura, H.; Song, H.; Sawamura, M.; Suganuma, N. Anti-inflammatory Effects of Limonene from Yuzu (Citrus junos Tanaka) Essential Oil on Eosinophils. J. Food Sci. 2010, 75, H87-H92. [CrossRef] [PubMed]

27. Crowell, P. Monoterpenes in breast cancer chemoprevention. Breast Cancer Res. Treat. 1997, 46, $191-197$. [CrossRef] [PubMed]

28. Omolo, M.O.; Okinyo, D.; Ndiege, I.O.; Lwande, W.; Hassanali, A. Repellency of essential oils of some Kenyan plants against Anopheles gambiae. Phytochemistry 2004, 65, 2797-2802. [CrossRef] [PubMed]

29. Da Fonseca, C.O.; Schwartsmann, G.; Fischer, J.; Nagel, J.; Futuro, D.; Quirico-Santos, T.; Gattass, C.R. Preliminary results from a phase I/II study of perillyl alcohol intranasal administration in adults with recurrent malignant gliomas. Surg. Neurol. 2008, 70, 259-266. [CrossRef] [PubMed]

30. Kennedy, S.; Wadsworth, R.M.; Wainwright, C.L. Effect of antiproliferative agents on vascular function in normal and in vitro balloon-injured porcine coronary arteries. Eur. J. Pharmacol. 2003, 481, 101-107. [CrossRef] [PubMed]

31. Saito, K.; Okabe, T.; Inamori, Y.; Tsujibo, H.; Miyake, Y.; Hiraoka, K.; Ishida, N. The biological properties of monoterpenes: Hypotensive effects on rats and antifungal activities on plant pathogenic fungi of monoterpenes. Mokuzai Gakkaishi 1996, 42, 677-680.

32. Baek, I.; Jeon, S.B.; Kim, J.; Seok, Y.M.; Song, M.-J.; Chae, S.C.; Jun, J.E.; Park, W.H.; Kim, I.K. A role for Rho-kinase in Ca-independent contractions induced by phorbol-12,13-dibutyrate. Clin. Exp. Pharmacol. Physiol. 2009, 36, 256-261. [CrossRef] [PubMed] 
33. Treiman, M.; Caspersen, C.; Brøgger, S. A tool coming of age: Thapsigargin as an inhibitor of sarcoendoplasmic reticulum $\mathrm{Ca}^{2+}$-ATPases. Trends Pharmacol. Sci. 1998, 19, 131-135. [CrossRef]

34. Somlyo, A.P.; Somlyo, A.V. Flash Photolysis Studies of Excitation-Contraction Coupling, Regulation, and Contraction in Smooth Muscle. Annu. Rev. Physiol. 1990, 52, 857-874. [CrossRef] [PubMed]

35. Quast, U. Do the $\mathrm{K}^{+}$channel openers relax smooth muscle by opening $\mathrm{K}+$ channels? Trends Pharmacol. Sci. 1993, 14, 332-337. [CrossRef]

36. Marom, M.; Hagalili, Y.; Sebag, A.; Tzvier, L.; Atlas, D. Conformational changes induced in voltage-gated calcium channel Cav1.2 by BayK 8644 or FPL64176 modify the kinetics of secretion independently of $\mathrm{Ca}^{2+}$ influx. J. Biol. Chem. 2010, 285, 6996-7005. [CrossRef] [PubMed]

37. Pinho-Da-Silva, L.; Mendes-Maia, P.V.; Teófilo, T.M.N.G.; Barbosa, R.; Ceccatto, V.M.; Coelho-De-Souza, A.N.; Santos-Cruz, J.; Leal-Cardoso, J.H. Trans-caryophyllene, a natural sesquiterpene, causes tracheal smooth muscle relaxation through blockade of voltage-dependent $\mathrm{Ca}^{2+}$ channels. Molecules 2012, 17, 11965-11977. [CrossRef] [PubMed]

38. Peixoto-Neves, D.; Leal-Cardoso, J.H.; Jaggar, J.H. Eugenol Dilates Rat Cerebral Arteries by Inhibiting Smooth Muscle Cell Voltage-dependent Calcium Channels. J. Cardiovasc. Pharmacol. 2014, 64, 401-406. [CrossRef] [PubMed]

39. Bolton, T.B.; Prestwich, S.; Zholos, V.; Gordienko, D.V. Excitation-contraction coupling in gastrointestinal and other smooth muscles. Annu. Rev. Physiol. 1999, 61, 85-115. [CrossRef] [PubMed]

40. Karaki, H.; Ozaki, H.; Hori, M. Calcium movements, distribution, and functions in smooth muscle. Pharmacol. Rev. 1997, 49, 157-230. [PubMed]

41. Whitney, G.; Throckmorton, D.; Isales, C.; Takuwa, Y.; Yeh, J.; Rasmussen, H.; Brophy, C. Kinase activation and smooth muscle contraction in the presence and absence of calcium. J. Vasc. Surg. 1995, 22, 37-44. [CrossRef]

42. Magalhães, P.J.C.; Criddle, D.N.; Tavares, R.; Melo, E.M.; Mota, T.L.; Leal-Cardoso, J.H. Intestinal myorelaxant and antispasmodic effects of the essential oil of Croton nepetaefolius and its constituents cineole, methyl-eugenol and terpineol. Phyther. Res. 1998, 12, 172-177. [CrossRef]

43. Török, J. Participation of nitric oxide in different models of experimental hypertension. Physiol. Res. 2008, 57, 813-825. [PubMed]

44. Furchgott, R.F.; Vanhoutte, P.M. Endothelium-derived relaxing and contracting factors. FASEB J. 1989, 3, 2007-2018. [CrossRef] [PubMed]

45. Furchgott, R. Role of endothelium in responses of vascular smooth muscle. Circ. Res. 1983, 53, 557-573. [CrossRef] [PubMed]

46. Hagiwara, S.; Mitsui, M.; Karaki, H. Effects of felodipine, nifedipine and verapamil on cytosolic $\mathrm{Ca}^{2+}$ and contraction in vascular smooth muscle. Eur. J. Pharmacol. 1993, 234, 1-7. [CrossRef]

47. Rembold, C.; Murphy, R. $\left[\mathrm{Ca}^{2+}\right]$-dependent myosin phosphorylation in phorbol diester stimulated smooth muscle contraction. Am. J. Physiol. Cell Physiol. 1988, 255, 719-723. [CrossRef] [PubMed]

48. Stankevicius, E.; Kevelaitis, E.; Vainorius, E.; Simonsen, U. Role of nitric oxide and other endothelium-derived factors. Medicina 2003, 39, 333-341. [PubMed]

49. Ruan, Y.C.; Zhou, W.; Chan, H.C. Regulation of smooth muscle contraction by the epithelium: Role of prostaglandins. Physiology 2011, 26, 156-170. [CrossRef] [PubMed]

50. O'Brien, R.F.; Robbins, R.J.; McMurtry, I.F. Endothelial cells in culture produce a vasoconstrictor substance. J. Cell. Physiol. 1987, 132, 263-270. [CrossRef] [PubMed]

51. Yanagisawa, M.; Kurihara, H.; Kimura, S.; Tomobe, Y.; Kobayashi, M.; Mitsui, Y.; Yazaki, Y.; Goto, K.; Masaki, T. A novel potent vasoconstrictor peptide produced by vascular endothelial cells. Nature 1988, 332, 411-415. [CrossRef] [PubMed]

52. Nerio, L.S.; Olivero-Verbel, J.; Stashenko, E. Repellent activity of essential oils: A review. Bioresour. Technol. 2010, 101, 372-378. [CrossRef] [PubMed]

Sample Availability: Samples of the compounds are not available from the authors.

(C) 2018 by the authors. Licensee MDPI, Basel, Switzerland. This article is an open access article distributed under the terms and conditions of the Creative Commons Attribution (CC BY) license (http:/ / creativecommons.org/licenses/by/4.0/). 